\title{
The chemopreventive effect of Ginkgo biloba and Silybum marianum extracts on hepatocarcinogenesis in rats
}

\author{
Hala O El Mesallamy ${ }^{1}$, Nadia S Metwally ${ }^{2 *}$, Mahmoud S Soliman², Kawkab A Ahmed ${ }^{3}$ and Mai M Abdel Moaty ${ }^{2}$
}

\begin{abstract}
Background/objective: This study was designed to evaluate the potential chemopreventive activities of Ginkgo biloba extract (EGb) and Silybum marianum extract (silymarin) against hepatocarcinogenesis induced by Nnitrosodiethylamine (NDEA) in rats.

Methods: Rats were divided into 6 groups. Group 1 served as normal control rats. Group 2 animals were intragastrically administrated NDEA at a dose of $10 \mathrm{mg} / \mathrm{kg}$ five times a week for 12 weeks to induce hepatocellular carcinoma (HCC). Groups 3 and 4 animals were pretreated with silymarin and EGb respectively. Groups 5 and 6 animals were posttreated with silymarin and EGb respectively. The investigated parameters in serum are alanine aminotransferase (ALT), aspartate aminotransferase (AST), gamma glutamyltransferase (GGT) and vascular endothelial growth factor (VEGF). The investigated parameters in liver tissue are malondialdehyde $(\mathrm{MDA})$, glutathione $(\mathrm{GSH})$, superoxide dismutase (SOD), glutathione peroxidase (GPx), glutathione reductase (GR) and comet assay parameters.
\end{abstract}

Results: In NDEA group, MDA level was elevated with subsequent decrease in GSH level and SOD, GPx and GR activities. In addition, NDEA group revealed a significant increase in serum ALT, AST and GGT activities and VEGF level. Furthermore, NDEA administrated animals showed a marked increase in comet assay parameters. These biochemical alterations induced by NDEA were confirmed by the histopathological examination of rat livers intoxicated with NDEA that showed an obvious cellular damage and well differentiated HCC.

In contrast, silymarin+NDEA treated groups (3\&5) and EGb+NDEA treated groups (4\&6) showed a significant decrease in MDA level and a significant increase in GSH content and SOD, GPX and GR activities compared to NDEA group. Silymarin and EGb also beneficially down-regulated the increase in serum ALT, AST, GGT activities and VEGF level induced by NDEA. In addition, silymarin and EGb significantly decreased comet assay parameters. Histopathological examination of rat livers treated with either silymarin or EGb exhibited an improvement in the liver architecture compared to NDEA group.

Conclusions: The obtained findings suggested that silymarin and EGb may have beneficial chemopreventive roles against hepatocarcinogenesis through their antioxidant, antiangiogenic and antigenotoxic activities.

Keywords: Hepatocellular carcinoma, Ginkgo biloba, Silybum marianum, N-nitrosodiethylamine, Antioxidants, Vascular endothelial growth factor, Comet assay

\footnotetext{
* Correspondence: nadiametwally@yahoo.com

${ }^{2}$ Therapeutical Chemistry Department, Pharmaceutical and Drug Industries Research Division, National Research Centre (NRC), Tahrir st., Dokki, Giza,

Egypt

Full list of author information is available at the end of the article
}

\section{Biomed Central}

(c) 2011 El Mesallamy et al; licensee BioMed Central Ltd. This is an Open Access article distributed under the terms of the Creative Commons Attribution License (http://creativecommons.org/licenses/by/2.0), which permits unrestricted use, distribution, and reproduction in any medium, provided the original work is properly cited. 


\section{Introduction}

Hepatocellular carcinoma is the fifth most common cancer worldwide and the third most common cause of cancer mortality with a continuously increasing incidence annually [1]. The major known risk factors for HCC are viral (chronic hepatitis B and hepatitis C), toxic (alcohol and aflatoxins), metabolic (diabetes and non alcoholic fatty liver disease, hereditary haemochromatosis), immune related (primary biliary cirrhosis and autoimmune hepatitis), food additives, environmental and industrial toxic chemicals and air and water pollutants [2]. In Egypt, between 1993 and 2002, there was an almost two-fold increase in HCC amongst chronic liver patients [3]. It has been found that hepatitis $\mathrm{C}$ virus $(\mathrm{HCV})$ and schistosomiasis play a major role in the development of HCC in Egypt where the highest prevalence of $\mathrm{HCV}$ in the world which has been attributed to previous public health eradication schemes for schistosomiasis $[4,5]$. Although there are many strategies for the treatment of HCC [6], its therapeutic outcome remains very poor. Therefore, preventive strategies are of paramount importance and need to be actively explored in order to reduce the incidence of this disease. The reduced cancer risk and lack of toxicity associated with high intake of natural products suggest that specific concentrations of phytochemicals from these plant sources may produce cancer chemopreventive effects without causing significant levels of toxicity. These natural products are believed to suppress the inflammatory process that lead to neoplastic transformation, hyperproliferation, promotion and progression of carcinogenic process and angiogenesis [7].

Silymarin, a standardized extract from Silybum marianum (milk thistle; a medicinal plant), has been extensively studied and has shown anticancer efficacy against various cancer sites $[8,9]$. This has been attributed to that silymarin interfers with the expression of cell cycle regulators and proteins involved in apoptosis. Additionally, silymarin has antioxidant properties and anti-metastatic activity [10]. Several studies have shown that silymarin has tumor suppressive effect on hepatocarcinogenesis [11-13].

Ginkgo biloba, a unique tree, is one of the best known examples of a living fossil. Ginkgo leaf extract has powerful anti-cancer properties through its antioxidant, gene-regulatory and antiangiogenic properties [14]. Ginkgo biloba extract may regulate cell proliferation and induce apoptosis of human hepatocellular cell lines: HepG2, Hep3B, and SMMC-7721 cells, therefore it may have protective effects against hepatocarcinogenesis $[15,16]$.

In the present study, we investigated the chemopreventive effects of Ginkgo biloba and Silybum marianum extracts as antioxidant, antiangiogenic and antigenotoxic substances against HCC induced by NDEA in experimental animals. This may be promising at stopping hepatocarcinogenesis, delaying its progress, minimizing the damage to liver cells or reducing its complications.

\section{Materials and methods \\ Animals}

Healthy male Wistar albino rats weighing 100-120 g supplied from the animal house of National Research Center (Dokki, Giza, Egypt) were used for this study. Animals were housed in cages under proper environmental conditions at room temperature $22-24^{\circ} \mathrm{C}$ and 12 $\mathrm{h}$ light/dark cycle and fed with a commercial pellet diet (Wadi El Kabda Co., Cairo, Egypt). The animals had free access to water. The animals were acclimatized to the laboratory conditions for two weeks before beginning the experiment. The experiment continued for 13 weeks on which constant weight of diet was given for each rat. All the experiments were designed and conducted according to the ethical norms approved by the Ethical Committee of National Research Center.

\section{Chemicals}

$\mathrm{N}$-nitrosodiethylamine and ethidium bromide were purchased from Sigma-Aldrich (St. Louis, MO, USA), vascular endothelial growth factor ELISA kit was purchased from RayBiotech, Inc. (Milford, MA, USA), AST and ALT kits were purchased from Stanbio laboratory (Boerne, TX, USA) and GGT kit was purchased from Centronic GmbH (Wartenberg, Germany). Silymarin was purchased from ACAPI Co. (Cairo, Egypt). Silymarin consists of $80 \% \mathrm{w} / \mathrm{w}$ of silybin with smaller amounts of isosilybin, dihydrosilybin, silydianin, and silychristin. EGb was purchased from EMA Pharm Co. (Cairo, Egypt). EGb consists of approximately $24 \%$ flavone glycosides (quercetin, kaempferol and isorhamnetin), 6\% terpene trilactones (ginkgolides A, B and C, bilobalide) and less than 5 ppm ginkgolic acid. All the other chemicals used were of high analytical grade and were purchased locally.

\section{Experimental design}

The experimental animals were divided into six groups (as shown in figure 1); each group was comprised of eight animals except group 2 which was comprised of 12 animals (4 rats were used for the confirmation of the induction of $\mathrm{HCC}$ at the end of $9^{\text {th }}$ week of the experiment by the histopathological examination of rat livers). Group 1: Normal control rats fed with standard diet for 13 weeks. Group 2: Rats were induced with HCC by NDEA received intragastrically at a dose of $10 \mathrm{mg} / \mathrm{kg}$ body weight 5 times a week for 12 weeks [17]. Group 3: Rats pretreated with silymarin $(100 \mathrm{mg} / \mathrm{kg}$ body weight daily) received intragastrically one week before the administration of NDEA and 


\section{$\begin{array}{llllllllllllll}0 & 1 & 2 & 3 & 4 & 5 & 6 & 7 & 8 & 9 & 10 & 11 & 12 & 13\end{array}$ \\ $\Delta$
$\Delta$$\Delta \Delta \Delta$ \\ $\triangle$
A Supplementation of silymarin and EGb for groups 3 and 4 respectively till the end of experiment.

$\triangle$ NDEA administration in groups (2-6) till the end of experiment.

\section{$\triangle$ Confirmation of the induction of HCC.}

\section{$\triangle$ Supplementation of silymarin and EGb for groups 5 and 6 respectively till the end of experiment.}

\section{$\triangle$ Dissection of rats.}

Figure 1 The experimental design diagram.

continued till the end of the experiment (i.e. 13 weeks) [18]. Group 4: Rats pretreated with EGb (100 mg/kg body weight daily) received intragastrically one week before the administration of NDEA and continued till the end of the experiment [19]. Group 5: Rats posttreated with silymarin $(100 \mathrm{mg} / \mathrm{kg}$ body weight daily) received intragastrically for 4 weeks after the administration of NDEA for 8 weeks and continued till the end of experiment [18]. Group 6: Rats posttreated with EGb (100 mg/kg body weight daily) received intragastrically for 4 weeks after the administration of NDEA for 8 weeks and continued till the end of experiment [19]. At the end of experimental period, the animals were fasted overnight then subjected to mild ether anesthesia and blood samples were collected. The blood was allowed to coagulate and centrifuged at $3000 \mathrm{rpm}$ for 15 minutes at $4^{\circ} \mathrm{C}$ to separate the serum to be used for biochemical analysis. After blood collection, rats were dissected then the livers were excised and small sections were cut with cold knife. The first liver section was used for the preparation of the liver tissue homogenate to be used for the biochemical tissue analysis. The second liver section was used for the histopathological examination. The third liver section was used for the comet assay.

\section{Biochemical analysis}

\section{Determination of liver function enzymes}

ALT and AST activities were determined in the sera of rats using Stanbio kit following the method described by Bergmeyer et al. [20]. GGT was measured in the sera of rats using Centronic GmbH- Germany Kit following the method described by Persijn and van der Slik [21].

\section{Determination of hepatic reduced glutathione, lipid peroxidation and antioxidant enzymes}

The hepatic GSH content was estimated by the method of Beutler et al. [22]. Lipid peroxidation was measured in the liver tissue as MDA level according to the method of Ruiz-Larrea et al. [23]. Glutathione reductase (GR) activity was assayed in the liver tissue according to the method of Erden and Bor [24]. Glutathione peroxidase (GPx) activity was estimated in the liver tissue by the method of Paglia and Valentine [25]. Superoxide dismutase (SOD) activity in the liver tissue was measured by the method of Nishikimi et al. [26]. Total proteins were assayed in the liver tissue according to the method of Bradford [27].

\section{Determination of vascular endothelial growth factor (VEGF)}

The measurement of VEGF in the sera of rats using ELISA technique according to the method of Ferrara [28] using rat VEGF ELISA kit, ELISA (Dynatech MR 5000, Midland, ON, Canada), Washer (Dynatech MRW, Gaithersburg, MD, USA), Shaker (Varishaker-Incupator, NJ, USA) and Printer (Panasonic Quiet KXP2123, Seri Kembangan, Selangor, Malaysia).

\section{Comet assay (single cell gel electrophoresis, SCGE)}

DNA damage was measured using the comet assay under alkaline conditions and dim indirect light. The 
SCGE assay was performed essentially as described with some modifications [29]. The liver was excised, washed in saline solution and a small fragment of the liver was transferred to a Petri dish kept on ice. The fragment was washed, minced and suspended into $1 \mathrm{ml}$ cold Hank's balanced salt solution (HBSS) containing 20 mM EDTA and 10\% dimethylsulphoxide (DMSO). The fragment was cut into smaller pieces using a disposable microtome razor blade and the solution was aspirated. A fresh mincing solution was added and the liver samples were minced again into finer pieces. The suspension containing isolated cells was transferred to a tube maintained on ice until the preparation of the slides [30]. The quantity of liver cells in the cell suspensions was determined in Giemsa-stained smears. From the liver cell suspension containing approximately $2 \times 10^{4}-5 \times 10^{4}$ cells $/ \mathrm{ml}, 5 \mu \mathrm{l}$ was removed and mixed with $95 \mu$ l of $0.5 \%$ low melting point agarose; LMPA (in $\mathrm{Ca}^{+2}$ and $\mathrm{Mg}^{+2}$ free PBS) to prepare the final cell-agarose suspension. From the final cellagarose suspension, $80 \mu \mathrm{l}$ was spread over the microscope slide $(75 \times 25 \mathrm{~mm}$ glass slides with $19 \mathrm{~mm}$ frosted ends, Gibco-BRL), pre-coated with $1 \%$ normal melting point agarose; NMPA (Gibco-BRL). The cells were then lysed in freshly prepared buffer containing $2.5 \mathrm{M} \mathrm{NaCl}$, $100 \mathrm{mM}$ EDTA, $10 \mathrm{mM}$ Tris (pH 10.0), 1\% Triton X-100 and $10 \%$ DMSO for $24 \mathrm{~h}$ at $4^{\circ} \mathrm{C}$. After lysis, the slides were rinsed three times in deionized water to remove salt and detergent. The slides were placed in a horizontal electrophoresis unit (Cleaver Scientific Ltd, UK) and DNA was allowed to unwind for $20 \mathrm{~min}$ in alkaline solution containing $300 \mathrm{mM} \mathrm{NaOH}$ and $1 \mathrm{mM}$ EDTA, $\mathrm{pH}$ > 13. The DNA was electrophoresed for $20 \mathrm{~min}$ at $300 \mathrm{~mA}$ and $30 \mathrm{~V}(0.90 \mathrm{~V} / \mathrm{cm})$. The slides were then neutralized with $0.4 \mathrm{~m}$ Tris ( $\mathrm{pH} 7.5$ ), fixed for $5 \mathrm{~min}$ in absolute alcohol, air-dried and stored at room temperature. Immediately before analysis, the DNA was stained with $50 \mu \mathrm{l}$ ethidium bromide $(20 \mu \mathrm{g} / \mathrm{ml})$.

\section{Data scoring and photomicrographs}

The fluorescent labeled DNA was visualized (magnification 400x) using an automated fluorescence microscope (Carl Zeiss, Germany) and the images were captured on a computer, equipped with CometScore software (Komet IV). Three parameters were adopted as indicators of DNA damage: tail length (TL in $\mu \mathrm{m}$ ),\% DNA in comet tail (\% DNA in tail) and tail moment (TM in arbitrary units, TM = TL X\% DNA in tail).\% DNA in tail is the most preferred parameter because it covers a wide range of damage and is linearly related to the break frequency [31].

\section{Histopathological examination}

Tissue specimens from liver were collected from all experimental groups at the end of experiment and fixed in neural buffered formalin $10 \%$, dehydrated in ascending concentration of ethanol, cleared in xylene and embedded in paraffin. Sections 4-5 $\mu \mathrm{m}$ in thickness were prepared and stained with Hematoxylin and Eosin [32].

\section{Statistical analysis}

The data obtained was statistically analyzed using SPSS software package (version 7.5). Hypothesis testing methods included one way analysis of variance (ANOVA) followed by least significant differences (LSD). Values are expressed as mean \pm S.D. $P$ value $\leq 0.05$ was considered significant.

\section{Results}

\section{Confirmation of the induction of HCC in rats}

During the experiment, we dissected four rats from NDEA treated group at the end of $9^{\text {th }}$ week of experiment (i.e the end of $8^{\text {th }}$ week of NDEA administration) and liver was examined histopathologically. The histopathological examination of the liver revealed that HCC was induced.

\section{Effect of silymarin and EGb on hepatic MDA, GSH and antioxidant enzymes}

A significant increase in MDA level was observed in NDEA treated rats compared to control rats (table 1). Prophylactic treatment with either silymarin or EGb for 13 weeks showed a significant protection against NDEA induced lipid peroxidation (table 1). Therapeutic treatment with either silymarin or EGb for 4 weeks offered a significant decrease in MDA level compared to NDEA treated rats (table 1). NDEA administration led to a significant depletion in hepatic GSH content compared with control rats (table 1). Pretreatment and posttreatment with either silymarin or EGb significantly improved hepatic GSH level compared to NDEA group (table 1). The activities of hepatic antioxidant enzymes; GR, GPx and SOD were significantly decreased in NDEA group compared with control animals (table 1). The pretreated and posttreated groups with either silymarin or EGb showed a significant increase in hepatic GR, GPx and SOD activities compared to NDEA intoxicated group (table 1).

\section{Effect of silymarin and EGb on serum transaminases and gamma glutamyltransferase}

The activities of serum ALT, AST and GGT were significantly increased in NDEA treated group compared to control group (table 2). Pretreatment and posttreatment with either silymarin or EGb significantly reduced the elevation in the serum ALT, AST and GGT activities induced by NDEA administration (table 2).

\section{Effect of silymarin and EGb on serum VEGF}

The serum VEGF level in NDEA group showed the most highly significant elevation compared to control 
Table 1 Hepatic MDA, GSH levels, GR, GPx and SOD activities in different experimental groups

\begin{tabular}{|c|c|c|c|c|c|}
\hline Groups & $\begin{array}{c}M D A \\
\text { (nmol MDA/g tissue) }\end{array}$ & $\begin{array}{c}\text { GSH } \\
\text { (mg/g tissue) }\end{array}$ & $\begin{array}{c}G R \\
\text { (nmol NADPH reacted } / \mathrm{min} / \mathrm{mg} \text { protein) }\end{array}$ & $\begin{array}{c}G P x \\
\text { (nmol NADPH reacted } / \mathrm{min} / \mathrm{mg} \text { protein) }\end{array}$ & $\begin{array}{c}S O D \\
\text { (nmol NADPH } \text { reacted/min/mg protein) }\end{array}$ \\
\hline Control & $11.65 \pm 1.10$ & $6.86 \pm 1.21$ & $85.94 \pm 5.74$ & $102.26 \pm 8.43$ & $49.34 \pm 3.08$ \\
\hline NDEA & $22.97 \pm 2.79^{a}$ & $0.43 \pm 0.10^{a}$ & $51.94 \pm 2.88^{a}$ & $18.34 \pm 3.49^{a}$ & $5.28 \pm 0.82^{a}$ \\
\hline Pre S.m & $13.89 \pm 1.89^{b}$ & $3.38 \pm 0.16^{b}$ & $72.44 \pm 3.91 \mathrm{~b}$ & $25.26 \pm 2.76^{b}$ & $37.04 \pm 4.76^{b}$ \\
\hline Pre G.b & $14.42 \pm 1.56^{b}$ & $4.54 \pm 1.00^{b}$ & $77.27 \pm 13.15^{b}$ & $36.63 \pm 4.10^{b}$ & $32.28 \pm 3.23^{b}$ \\
\hline Post S.m & $16.74 \pm 2.90^{b, c}$ & $2.36 \pm 0.45^{b, c}$ & $62.51 \pm 5.50^{b, c}$ & $20.00 \pm 1.67^{c}$ & $17.39 \pm 2.40^{b, c}$ \\
\hline Post G.b & $17.53 \pm 3.32^{b, d}$ & $3.64 \pm 0.57^{b, d}$ & $61.47 \pm 6.42^{b, d}$ & $29.84 \pm 2.92^{b, d}$ & $20.92 \pm 1.77^{b, d}$ \\
\hline
\end{tabular}

Results are given as mean \pm S.D. for 6 rats. Pre S.m = Pretreated silymarin, Pre G.b = Pretreated EGb, Post S.m = Posttreated silymarin, Post G.b = Posttreated EGb. a: significantly different from control group at $p \leq$ 0.05. b: significantly different from NDEA group at $p \leq 0.05$. c: significantly different from Pre S.m group at $p \leq 0.05$. d: significantly different from Pre G.b group at $p \leq 0.05$. 
Table 2 Effect of silymarin and Ginkgo biloba extract on ALT, AST and GGT activities in the sera of rats of different experimental groups

\begin{tabular}{|c|c|c|c|}
\hline Groups & $A L T(U / L)$ & $A S T(U / L)$ & $G G T(U / L)$ \\
\hline Control & $23.05 \pm 1.68$ & $62.47 \pm 3.65$ & $31.68 \pm 4.38$ \\
\hline$N D E A$ & $75.20 \pm 1.52^{a}$ & $101.22 \pm 2.66^{a}$ & $87.84 \pm 10.45^{a}$ \\
\hline Pre S.m & $41.43 \pm 1.13^{b}$ & $82.27 \pm 1.54^{b}$ & $53.02 \pm 4.77^{b}$ \\
\hline Pre G.b & $36.09 \pm 1.24^{b}$ & $81.62 \pm 3.05^{b}$ & $53.29 \pm 7.68^{b}$ \\
\hline Post S.m & $53.55 \pm 2.48^{b c}$ & $92.23 \pm 6.24 \mathrm{bc}$ & $68.03 \pm 5.36^{b c}$ \\
\hline Post G.b & $46.97 \pm 2.09 \mathrm{bd}$ & $95.47 \pm 3.71^{b d}$ & $68.27 \pm 8.39 \mathrm{bd}$ \\
\hline
\end{tabular}

Results are given as mean \pm S.D. for 6 rats. Pre S. $m=$ Pretreated silymarin, Pre $G . b=$ Pretreated EGb, Post S.m = Posttreated silymarin, Post G.b = Posttreated EGb. a: significantly different from control group at $p \leq 0.05$. b: significantly different from NDEA group at $p \leq 0.05$. c: significantly different from Pre S.m group at $p \leq 0.05$. d: significantly different from Pre G.b group at $p \leq 0.05$.

rats (figure 2). All treated groups with either silymarin or EGb showed a significant reduction in serum VEGF level compared to NDEA intoxicated group (figure 2).

\section{Effect of silymarin and EGb on DNA damage}

A significant increase in different comet assay parameters (TL,\% DNA in tail and TM) has been shown in animals receiving NDEA compared with the negative control animals (figure 3). Prophylactic and therapeutic treatment with either silymarin or EGb significantly reduced NDEA induced DNA damage as indicated by reduction in different comet assay parameters (TL, \% DNA in tail and TM) (figure 3). Photomicrographs of comets in the hepatocytes stained with ethidium bromide in different experimental groups are illustrated in figure (4).

\section{Effect of silymarin and EGb on liver histopathology}

Histopathological examination of liver sections from control group revealed normal architecture (figure 5a). While, liver sections of NDEA administered animals revealed well differentiated HCC with apoptosis of hepatocytes, mitotic figures, megalocytosis, foamy cytoplasm and hyperchromatic nuclei (figure 5b). Liver sections of rats pretreated with either silymarin or EGb restored many of normal hepatic architecture with less disarrangement and degeneration of hepatocytes, minimal nuclear vesiculation and nuclear prominence compared with NDEA treated group (figure 5c,d). Meanwhile, liver sections of rats posttreated with either silymarin or EGb revealed slight improvement in the hepatocytes compared with NDEA treated group. Liver sections of rats posttreated with silymarin revealed lesser degree of cytomegalic and vacuolated hepatocytes with minimal nuclear vesiculation and nuclear prominence compared to $\mathrm{HCC}$-induced animals (figure 5e). The proliferation of oval cells had been also observed (figure 5e). Liver sections of rats posttreated with EGb revealed lesser degree of vacuolated hepatocytes and kupffer cells activation compared with NDEA treated group (figure 5f).

\section{Discussion}

$\mathrm{N}$-nitrosodiethylamine, as a well known potent hepatocarcinogenic agent, may be present in tobacco smoke, water, cured and fried meals, cheddar cheese, agricultural chemicals, cosmetics and pharmaceutical products. It is also found in minute concentrations in baby bottle nipples [33]. Metabolism of certain therapeutic drugs is also reported to produce NDEA [34].

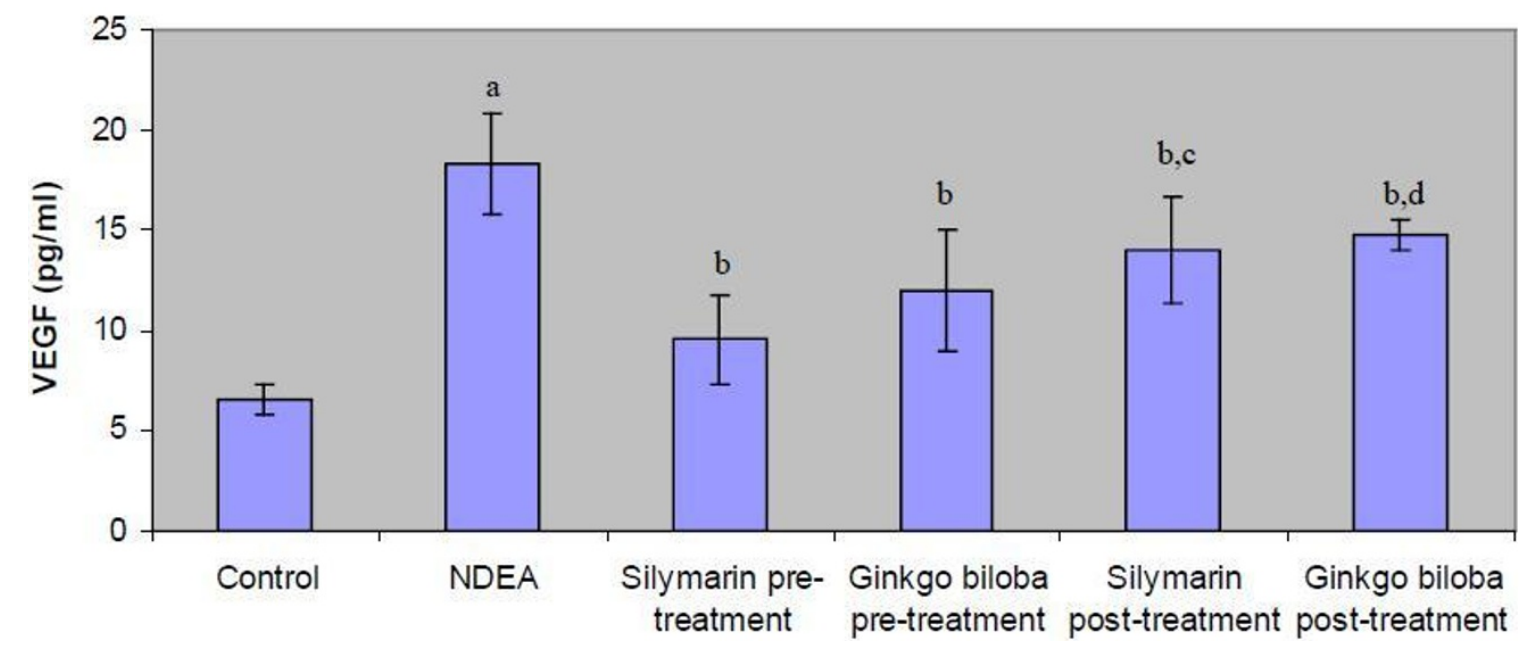

Figure 2 Serum VEGF level of the rats of different experimental groups. Results are given as mean \pm S.D. for 6 rats. a: significantly different from control group at $p \leq 0.05$. b: significantly different from NDEA group at $p \leq 0.05$. c: significantly different from silymarin pretreated group at $p \leq 0.05$. d: significantly different from Ginkgo biloba pretreated group at $p \leq 0.05$. 

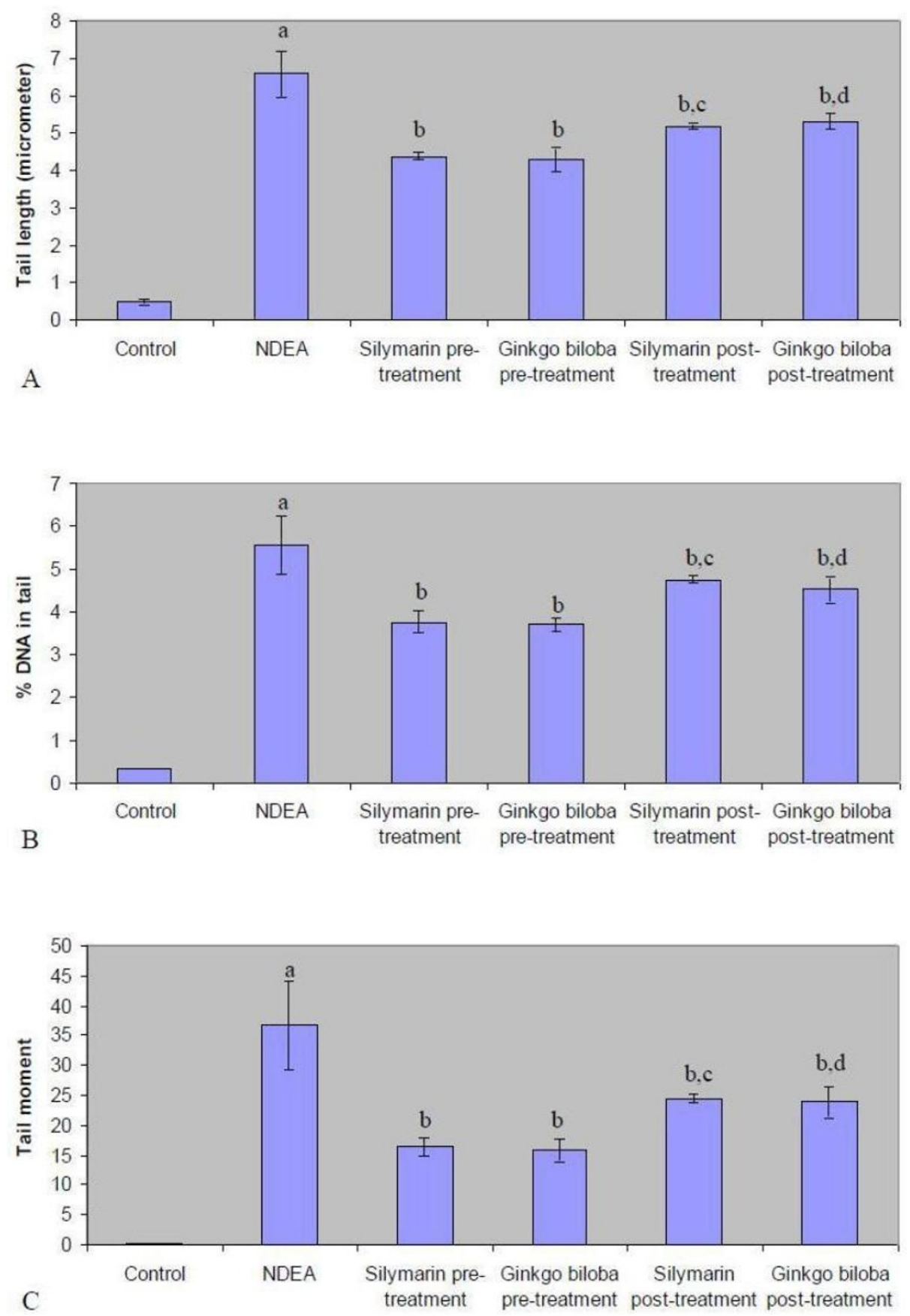

Figure 3 Comet assay parameters in the hepatic tissue of rats of different experimental groups. Results are given as mean \pm S.D. for 4 rats. a: significantly different from control group at $p \leq 0.05$. b: significantly different from NDEA group at $p \leq 0.05$. c: significantly different from silymarin pretreated group at $p \leq 0.05$. d: significantly different from Ginkgo biloba pretreated group at $p \leq 0.05$.

Data presented in our investigation indicated that administration of NDEA lead to induction of HCC and augmentation of oxidative stress in livers of NDEA treated rats. NDEA impaired antioxidative defense as indicated by a significant elevation in the level of oxidative stress marker (MDA) and a significant depletion of free radical scavenging antioxidants (GR, GPx, SOD and GSH). The oxidative stress in livers of HCC-induced rats may be attributed to that NDEA is mainly metabolized in the liver by the action of cytochrome $\mathrm{p} 450$ enzymes and the reactive metabolites are primarily responsible for its hepatotoxic effects. NDEA is 

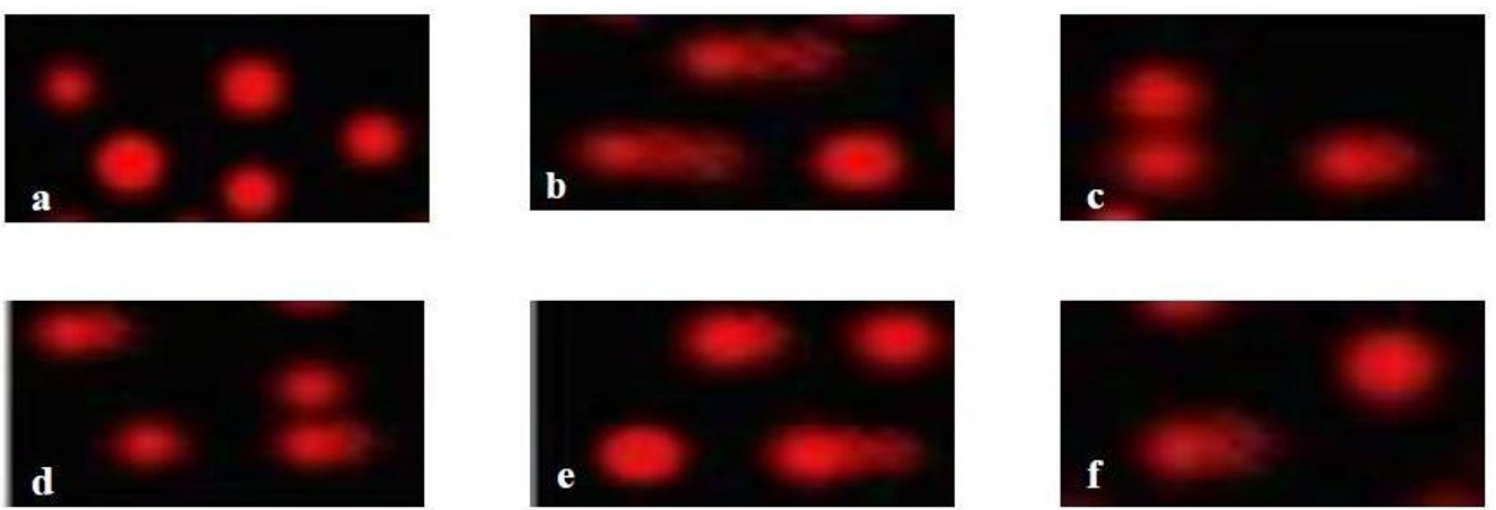

Figure 4 Photomicrographs of comets in the hepatocytes stained with ethidium bromide in different experimental groups. Control (a) NDEA (b), Silymarin pretreated (c), EGb pre-treated (d), Silymarin post-treated (e) and EGb post-treated (f) (400x).

bioactivated to ethyldiazonium ion which alkylates DNA bases to form promutagenic adducts such as $\mathrm{O}^{6}$-ethyldeoxyguanosine and $\mathrm{O}^{4}$ and $\mathrm{O}^{6}$-ethyldeoxythymidine and these ROS induce oxidative stress and cytotoxicity by damaging biomolecules such as DNA, lipids and proteins [35]. Depletion in GSH level and GSH dependent enzymes, GPx and GR, in NDEA treated rats might be attributed to the reduction in their biosynthesis during hepatocellular damage or their excessive utilization in scavenging the free radicals formed during the metabolism of NDEA. Furthermore, the decreased levels of cellular GSH might have caused a reduction in the activities of GSH dependent enzymes, GPx and GR, as GSH is a vital co-factor for these enzymes [11,36].

Supplementation of the extracts under investigation (silymarin and EGb) to NDEA treated animals effectively
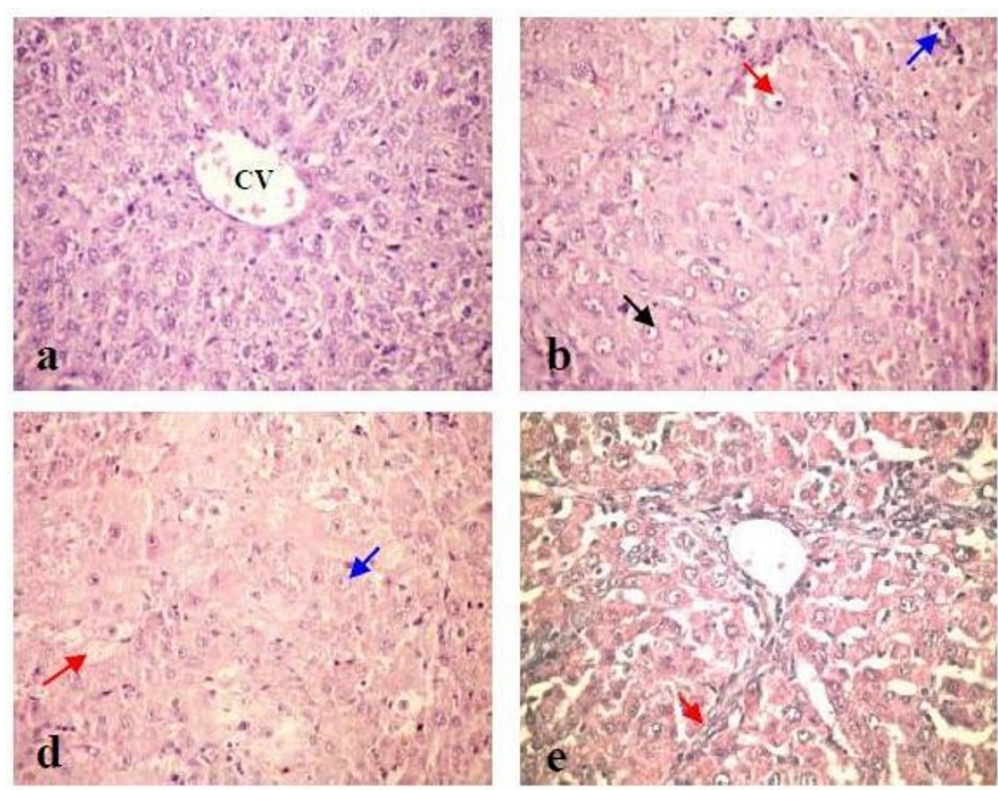
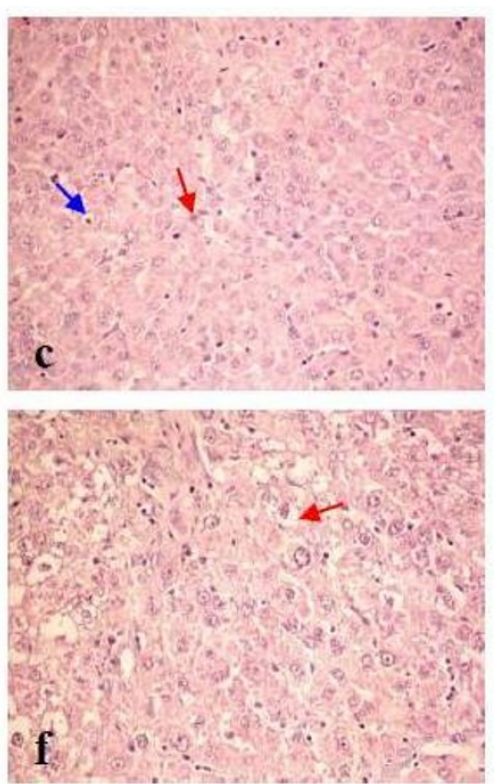

Figure 5 Histopathological photomicrographs of the liver of rats of different experimental groups. (a) Liver from control group showing normal hepatic architecture with the central vein (CV) lying at the center of the hepatic lobule surrounded by the hepatocytes ( $H$ \& $E$ stain- $X$ 400). (b) Liver from NDEA administrated group showing disorganization of hepatic lobular architecture and obvious cellular damage. The hepatocytes lost their normal shape, lost their arrangement and showed megalocytosis (red arrow), hyperchromatic nuclei (blue arrow) as well as nuclear vesiculation and nuclear prominence (black arrow) (H \& E stain-X 400). (c) Liver from silymarin pretreated group showing Kupffer cells proliferation (red arrow), minimal nuclear vesiculation and nuclear prominence (blue arrow) (H \& E stain-X 400). (d) Liver from EGb pretreated group showing hepatocytes with foamy cytoplasm (red arrow), minimal nuclear vesiculation and nuclear prominence (blue arrow) ( $\mathrm{H}$ \& $\mathrm{E}$ stain-X 400). (e) Liver from silymarin posttreated group showing oval cells proliferation (red arrow) (H \& E stain-X 400). (f) Liver from EGb posttreated group showing lesser degree of vacuolated hepatocytes (red arrow) (H \& E stain-X 400). 
modulates the deterioration in the oxidative stress marker, MDA as well as the antioxidant indices, SOD, GR, GPx and GSH implying the beneficial antioxidant abilities of these extracts. Supporting our findings with silymarin, Ramakrishnan et al. [37] reported a significant decrease in lipid peroxidation with a significant increase in GSH level as well as an improvement in the activities of the antioxidant enzymes, GR and GPx in the haemolysate and the liver of silymarin treated animals compared to NDEA treated animals. These revealed the anti-lipid peroxidative activity of silymarin and its ability to inhibit free radical generation. The increase in GSH may reduce the DNA-carcinogen interaction by providing a large nucleophilic pool for electrophilic carcinogen (NDEA). GSH neutralizes the electrophilic site by providing $\mathrm{SH}$ group and renders the metabolite more water soluble [38]. It has been reported that there is an improvement in the activities of the antioxidant enzymes as NADPH required for the production of GSH is produced by the pentose phosphate pathway [39]. Silymarin has the ability to increase the glucose uptake in the cells which might enhance the levels of glucose uptake by the cells that ultimately serves as fuel for both pentose phosphate pathway and oxidative phosphorylation thereby bringing up the cellular levels of $\mathrm{NADPH} / \mathrm{NADP}^{+}$. Increasing the levels of NADPH, GR activity also is improved thereby raising the levels of the GSH, the substrate for GPx [40]. Supporting our findings with EGb, Naik and Panda [41] reported that EGb significantly increased the activities of free radical scavenging enzymes, SOD, GPx, GR and catalase and the non-enzymatic antioxidant, $\mathrm{GSH}$ in $\mathrm{CCl}_{4}$-treated rats compared with $\mathrm{CCl}_{4}$ treatment alone. Ginkgo biloba extract inhibits lipid peroxidation by scavenging free radicals and ROS maintaining the integrity and permeability of cell membranes thereby protecting cells and tissues against oxidative stress induced by the free radicals [42]. These beneficial effects of EGb could be explained not only by its antioxidant properties, but also by its ability to inhibit the main cytochrome P450 isoenzyme 2E1 (CYP2E1) that metabolizes NDEA and $\mathrm{CCl}_{4}$ inducing ROS generation and lipid peroxidation $[35,43]$.

Researchers recognize that tumor growth is angiogenesis-dependent and every increment of tumor growth requires an increment of vascular growth. Tumors lacking angiogenesis remain dormant indefinitely and rapid logarithmic growth follows the acquisition of a blood supply. Therefore, many researchers show great interests in identifying and modulating antiangiogenic pathways and developing antiangiogenic drugs for therapeutic purposes $[14,44]$. VEGF is one of the most important angiogenic cytokines. The overexpression of VEGF has been shown to enhance tumor growth and its expression correlates with poor prognosis in several types of tumors including $\mathrm{HCC}$ which is a typical hypervascular tumor [45]. Data in the present study showed that the serum VEGF level in NDEA treated rats was significantly elevated compared to the normal healthy rats. Liu et al. [46] reported that the expression of VEGF in NDEA treated group was remarkably elevated and no positive expression of VEGF was found in the negative control group. These results might be attributed to the high angiogenic activity in NDEA-induced hepatocarcinoma rats, in addition to the increase of nitric oxide activity in NDEA treated animals compared to the negative control animals, thus enhancing the angiogenesis by stimulating the synthesis of VEGF [47]. Turlin et al. [48] also reported an overexpression of VEGF in hepatic foci and tumors in NDEA treated animals, this high expression was associated with breakdown of the vascular wall by tumor cells. Since VEGF can act as a permeability factor, this suggests a relationship between VEGF expression and invasion of the vascular wall. Indeed, VEGF may induce a breakdown of vascular walls by inducing protease synthesis which may result in damaging vascular structures [49].

The current investigation revealed a significant decrease in serum VEGF level in silymarin supplemented rats compared to NDEA treated animals. Our results are in accordance with Jiang et al. [50] who reported that silymarin has antiangiogenic activity that may contribute critically to its cancer chemopreventive potential. The antiangiogenic effect of silymarin might be attributed to its rapid inhibitory action on the secretion of the primary angiogenic cytokine VEGF by the cancer epithelial cells. Also, silymarin inhibited endothelial matrix metalloproteinase-2 (MMP-2) secretion and expression, thus silymarin may provide an inhibitory mechanism on angiogenesis independent of its effect on VEGF [51]. Additionally, silybin (the main active constituent of silymarin) decreased the expression of hypoxia inducible factor-1 $\alpha$ (HIF-1 $\alpha)$ and inducible nitric oxide synthase (iNOS) that induce angiogenesis [52]. The current investigation also revealed a significant decrease in serum VEGF level in EGb supplemented rats compared to NDEA treated animals. Recent study demonstrated the requirement for the extracellular signal-regulated kinase (ERK) in growth factor induced angiogenesis. It has been shown that EGb reduces ERK phosphorylation induced by the growth factors VEGF and fibroblast growth factor (FGF) in an endothelial cell model leading to the suggestion that EGb inhibits angiogenesis via ERK inhibition as EGb activates protein tyrosine phosphatases [53]. It has been also shown that EGb inhibits the "respiratory (oxidative) burst" that results from the activation of human neutrophils, an action that could be associated with antiangiogenic and antitumorigenic activities because activated human neutrophils have 
been shown to be directly angiogenic via their release of VEGF and hepatocyte growth factor/scatter factor, two cytokines that have potent proangiogenic properties $[54,55]$.

The comet assay (SCGE) is a rapid, sensitive and versatile method for the quantification of DNA damage in the individual cells both in vitro and in vivo [56]. In the comet assay, cells with damaged DNA displayed increased migration of DNA fragments (comet tail) from the nucleoid (comet head) which may also be a feature of DNA fragmentation associated with the necrotic/apoptotic death process [57]. The current investigation demonstrated a highly significant increase in the comet assay parameters (TL,\% DNA in tail and TM) in NDEA treated rats compared to the healthy control rats. This is in consistent with the previous results of Horst et al. [58] who reported NDEAinduced DNA damage indicated by the markedly increased length of the comets (head + tail) in the liver cells of rats administrated NDEA compared to the negative control rats. The increment of such parameters may be due to that the enzymes of CYP2E1 subfamily play a role in the biotransformation of a range of compounds, including NDEA, producing the promutagenic DNA lesions which play an important role in DNA damage and induction of hepatocarcinogenesis [35].

Silymarin supplementation in our study was effective in suppressing DNA damage induced by NDEA showing a significant decrease in the comet assay parameters (TL,\% DNA in tail and TM) compared to NDEA treated group. These results were consistent with Saravanan and Pugalendi [59] who reported that the coadministration of silymarin with alcohol significantly decreased the DNA damage when compared with alcohol treated rats. This protective effect of silymarin can be explained by its ability to scavenge the free radicals before they cause damage to nuclear DNA [60]. Ginkgo biloba extract supplementation in our study significantly diminished DNA damage caused by NDEA as indicated by a significant decrease in the comet assay parameters (TL,\% DNA in tail and TM) compared to NDEA treated group. This was attributed to that EGb is cytoprotective; it is able to permeate cell membranes and exert its protective action on the nuclear DNA and also cytoplasmic components [61]. Keles et al. [62] reported that pretreatment with EGb clearly diminished 8-hydroxydeoxyguanosine (8-OHdG) formation in DNA in the hepatic tissue of rats that had undergone liver ischaemia-reperfusion (IR). This protective effect of EGb has been attributed to its high free radical scavenging ability. Min and Ebeler [63] suggested the potential of quercetin (the major component of flavonoid glycosides of EGb) to protect against cancer by inhibiting oxidative DNA damage as well as by enhancing DNA repair after oxidant challenge in Caco- 2 cells (colon cells).

Serum AST and ALT are the most sensitive markers employed in the diagnosis of hepatic damage because they are cytoplasmic in location and hence released into the circulation after cellular damage. Analysis of these marker enzymes reflects mechanisms of cellular damage, subsequent release of proteins, their extracellular turnover and mechanisms of neoplastic processes [64]. GGT is an enzyme embedded in the hepatocyte plasma membrane mainly in the canalicular domain and its liberation into serum indicates damage to the cell, thus injury to the liver [65]. The present study demonstrated that activities of ALT, AST and GGT in the sera of NDEA treated rats were markedly elevated compared to the normal healthy control rats. This increment is due to the production of free radicals during NDEA metabolism, thus damaging the hepatocellular membrane. As a result, these cytoplasmic enzymes are released into the systemic circulation.

As seen in the present study, treatment with silymarin significantly reduced serum ALT, AST and GGT activities compared to NDEA treated animals. This might be attributed to the ability of silymarin to scavenge the free radicals, thus preventing the hepatocellular damage caused by NDEA, thereby suppressing the leakage of enzymes through plasma membranes [11]. Supplementation of EGb to HHC-induced animals effectively lowers the high serum activities of AST, ALT and GGT produced by NDEA. This hepatoprotective effect of EGb could be due to a modifying influence on the biotransformation/detoxification of NDEA, thus reducing its liver toxicity [66].

The biochemical findings in our study were supported by the histopathological examination of the liver tissue of experimental animals. The histopathological observation of the livers of NDEA treated rats revealed well differentiated HCC with disorganization of hepatic lobular architecture and obvious cellular damage. The hepatocytes exhibited megalocytosis, foamy cytoplasm and hyperchromatic nuclei. This is in agreement with the results of Gupta et al. [67] who reported that the histological examination of the liver tissue of rats treated with NDEA revealed vacuolization, loss of normal hepatocellular architecture and the presence of pycnotic nuclei. This may be attributed to that NDEA is primarily metabolized in the liver and reactive metabolites generated thereby are known to damage hepatocytes.

Histopathology of the liver tissue of rats pretreated with silymarin revealed an improvement in the hepatocytes exhibiting less disarrangement and degeneration of hepatocytes compared to NDEA treated rats. Liver sections of rats posttreated with silymarin revealed a slight improvement in the hepatocytes exhibiting lesser degree 
of cytomegalic, vacuolated hepatocytes with minimal nuclear vesiculation and prominence compared with NDEA treated group. This improvement may be attributed to that silymarin can efficiently reduce intracellular ROS levels of hepatocytes, thus preventing oxidative stress-induced cellular damage. Furthermore, hepatic cell proliferation was found to be stimulated after silymarin treatment suggesting that enhanced liver regeneration may help replace the damaged liver cells [12]. Liver sections of rats pretreated with EGb revealed an improvement in the hepatocytes exhibiting less disarrangement and degeneration of hepatocytes compared with NDEA treated group. The liver sections of rats posttreated with EGb revealed a slight improvement in the hepatocytes exhibiting lesser degree of vacuolated hepatocytes and kupffer cells activation compared with NDEA treated group. These beneficial effects of EGb can be partially explained by its antioxidant properties and by inhibition of CYP2E1 that metabolizes NDEA in the liver [35].

Our study revealed that pretreatment with silymarin and Ginkgo biloba extract presented more protection of liver against NDEA induced damage than posttreatment with these extracts. Therefore, the chemopreventive activities of silymarin and Ginkgo biloba extract during initiation stage are more effective than post-initiation stage of rat hepatocarcinogenesis induced by NDEA. In conclusion, this study demonstrated that silymarin and Ginkgo biloba extract have been found to possess a beneficial protective effect against NDEA-induced hepatocarcinogenesis through their antioxidant, antigenotoxic and antiangiogenic activities. From this, we can hypothesize that these extracts are strong candidates as chemopreventive agents for liver cancer.

\section{Author details \\ ${ }^{1}$ Faculty of Pharmacy, Biochemistry Department, Ain Shams University, Abbassia, Cairo 11566, Egypt. ${ }^{2}$ Therapeutical Chemistry Department, Pharmaceutical and Drug Industries Research Division, National Research Centre (NRC), Tahrir st., Dokki, Giza, Egypt. ${ }^{3}$ Faculty of Veterinary Medicine, Pathology Department, Cairo University, Giza, Egypt.}

\section{Authors' contributions}

HOE conceived of the study, developed the study protocol, supervised the experimental work and corrected the manuscript. NSM participated in the protocol writing, supervised samples' analysis and helped to draft the manuscript. MSS participated in the protocol writing, designed the experiments, supervised samples' analysis and helped to draft the manuscript. KAA was responsible for the histopathological part of the study. MMA carried out all the experimental work, performed the statistical analysis and contributed to the writing of the manuscript. All authors read and approved the final manuscript.

\section{Competing interests}

The authors declare that they have no competing interests.

Received: 5 September 2011 Accepted: 31 October 2011 Published: 31 October 2011

\section{References}

1. World Health Organization. Mortality database. [http://www.who.int/ whosis/en].

2. Farazi1 PA, DePinho RA: Hepatocellular carcinoma pathogenesis: from genes to environment. Nat Rev Cancer 2006, 6:674-687.

3. El-Zayadi AR, Badran HM, Barakat EM, Attia MD, Shawky S, Mohamed MK, Selim O, Saeid A: Hepatocellular carcinoma in Egypt: a single center study over a decade. World J Gastroenterol 2005, 11:5193-5198.

4. Frank C, Mohamed MK, Strickland GT, Lavanchy D, Arthur RR, Magder LS, El Khoby T, Abdel-Wahab Y, Aly OES, Anwar W, Sallam I: The role of parenteral antischistosomal therapy in the spread of hepatitis $C$ virus in Egypt. Lancet 2000, 355:887-891.

5. Hassan MM, Zaghloul AS, El-Serag HB, Soliman O, Patt YZ, Chappell CL, Beasley RP, Hwang LY: The role of hepatitis $C$ in hepatocellular carcinoma: a case control study among Egyptian patients. J Clin Gastroenterol 2001, 33:123-126.

6. Blum HE: Hepatocellular carcinoma: Therapy and prevention. World J Gastroenterol 2005, 11(47):7391-7400.

7. Ramasamy K, Agarwal R: Multitargeted therapy of cancer by silymarin. Cancer Lett 2008, 269(2):352-362.

8. Deep G, Agarwal R: Chemopreventive efficacy of silymarin in skin and prostate cancer. Integr Cancer Ther 2007, 6:130-145.

9. Tyagi A, Raina K, Singh RP, Gu M, Agarwal C, Harrison G, Glode LM, Agarwal $\mathrm{R}$ : Chemopreventive effects of silymarin and silibinin on $\mathrm{N}$ butyl-N-(4-hydroxybutyl) nitrosamine induced urinary bladder carcinogenesis in male ICR mice. Mol Cancer Ther 2007, 6:3248-3255.

10. Agarwal $R$, Agarwal $C$, Ichikawa $H$, Singh RP, Aggarwal BB: Anticancer potential of silymarin: from bench to bed side. Anticancer Res 2006, 26:4457-4498.

11. Pradeep K, Mohan CVR, Gobianand K, Karthikeyan S: Silymarin modulates the oxidant-antioxidant imbalance during diethylnitrosamine induced oxidative stress in rats. Eur J Pharmacol 2007, 560:110-116.

12. Wu YF, Fu SL, Kao CH, Yang CW, Lin CH, Hsu MT, Tsai TF: Chemopreventive Effect of Silymarin on Liver Pathology in HBV X Protein Transgenic Mice. Cancer Res 2008, 68:2033-2042.

13. Shaarawy SM, Tohamy AA, Elgendy SM, Abd Elmageed ZY, Bahnasy A Mohamed MS, Kandil E, Matrougui K: Protective Effects of Garlic and Silymarin on NDEA-Induced Rats Hepatotoxicity. Int J Biol Sci 2009, 5(6):549-557

14. Sagar SM, Yance D, Wong RK: Natural health products that inhibit angiogenesis: a potential source for investigational new agents to treat cancer-Part 1. Curr Oncol 2006, 13:14-26.

15. Chen Q, Yang GW, An LG: Apoptosis of hepatoma cells SMMC-7721 induced by Ginkgo biloba seed polysaccharide. World J Gastroenterol 2002, 8:832-836.

16. Chao JC, Chu CC: Effects of Ginkgo biloba extract on cell proliferation and cytotoxicity in human hepatocellular carcinoma cells. World J Gastroenterol 2004, 10:37-41.

17. Karimov KhY, Inoyatova FKh, Mukhamedova MT: Changes in some indices of the synthesis of nitric oxide during the early stages of hepatocarcinogenesis. Exp Toxicol Pathol 2003, 55(1):17-19

18. Roy CK, Das AK: Comparative evaluation of different extracts of leaves of Psidium guajava linn. for hepatoprotective activity. Pak J Pharm Sci 2010, 23(1):15-20.

19. Welt K, Weiss J, Martin R, Hermsdorf T, Drews S, Fitzl G: Ginkgo biloba extract protects rat kidney from diabetic and hypoxic damage. Phytomedicine 2007, 14:196-203.

20. Bergmeyer HU, Scheibe P, Wahlefeld AW: Optimization of methods for aspartate aminotransferase and alanine aminotransferase. Clin Chem 1978, 24:58-61.

21. Persijn JP, van der Slik W: A new method for the determination of gamma-glutamyltransferase in serum. J Clin Chem Clin Biochem 1976, 14(9):421-427.

22. Beutler $E$, Duron $O$, Kelly B: Improved method for determination of blood glutathione. J Lab Clin Med 1963, 61:882-888.

23. Ruiz-Larrea MB, Leal AM, Liza M, Lacort M, de Groot H: Antioxidant effects of estradiol and 2-hydroxyestradiol on iron-induced lipid peroxidation of rat liver microsomes. Steroids 1994, 59(6):383-388.

24. Erden $M$, Bor NM: Changes in reduced glutathione, glutathione reductase and glutathione peroxidase after radiation in guinea pigs. Biochem Med $1984,31: 217-227$. 
25. Paglia DE, Valentine WN: Studies on the quantitative and qualitative characterization of erythrocyte glutathione peroxidase. J Lab Clin Med 1967, 70:158-169.

26. Nishikimi M, Rao NA, Yagi K: The occurrence of superoxide anion in the reaction of reduced phenazine methosulfate and molecular oxygen. Biochem Biophys Res Commun 1972, 46:849-854.

27. Bradford MM: A rapid and sensitive method for the quantitation of microgram quantities of protein utilizing the principle of protein-dye binding. Anal Biochem 1976, 72:248-254

28. Ferrara $\mathrm{N}$ : The vascular endothelial growth factor family of polypeptides. Cell Biochem 1991, 47:211-218.

29. Singh NP, McCoy MT, Tice RR, Schneider EL: A simple technique for quantitation of low levels of DNA damage in individual cells. Exp Cell Res 1988, 175:184-191.

30. Agner AR, Barbisan LF, Scolastici C, Salvadori DM: Absence of carcinogenic and anticarcinogenic effects of annatto in the rat liver medium-term assay. Food Chem Toxicol 2004, 42:1687-1693.

31. Collins AR, Oscoz AA, Brunborg G, Gaivão I, Giovannelli L, Kruszewski M, Smith CC, Stetina R: The comet assay: topical issues. Mutagenesis 2008, 23(3):143-151.

32. Bancroft D, Stevens A, Tuner R: Theory and practice of histological techniques. 4 edition. Edinburgh, London, Melbourne: Churchill Livingstone; 1996.

33. Brown JL: N-Nitrosamines. Occup Med 1999, 14:839-848.

34. Akintonwa DA: The derivation of nitrosamines from some therapeutic amines in the human environment. Ecotoxicol Environ Saf 1985, 9:64-70.

35. Verna L, Whysner J, Williams GM: N-Nitrodiethylamine mechanistic data and risk assessment: bioactivation, DNA-adduct formation, mutagenicity, and tumor initiation. Pharmacol Ther 1996, 71:57-81.

36. Seven A, Guzel S, Seymen O, Civelek S, Bolayirli M, Uncu M, Burcak G: Effects of vitamin $E$ supplementation on oxidative stress in streptozotocin induced diabetic rats: investigation of liver and plasma. Yonsei Med J 2004, 45:703-710.

37. Ramakrishnan G, Raghavendran HRB, Vinodhkumar R, Devaki T: Suppression of $\mathrm{N}$-nitrosodiethylamine induced hepatocarcinogenesis by silymarin in rats. Chemico-Biological Interactions 2006, 161:104-114.

38. Habig WH, Pabst MJ, Jakoby WB: Glutathione S-transferases. The first enzymatic step in mercapturic acid formation. J Biol Chem 1974, 249:7130-7139.

39. Gaetani GF, Galiano S, Canepa L, Ferraris AM, Kirkman HN: Catalase and glutathione peroxidase are equally active in detoxification of hydrogen peroxide in human erythrocytes. Blood 1989, 73:334-339.

40. Soto CP, Perez BL, Favari LP, Reyes JL: Prevention of alloxan-induced diabetes mellitus in the rat by silymarin. Comp Biochem Physiol C Pharmacol Toxicol Endocrinol 1998, 119(2):125-129.

41. Naik SR, Panda VS: Antioxidant and hepatoprotective effects of Ginkgo biloba phytosomes in carbon tetrachloride-induced liver injury in rodents. Liver Int 2007, 27(3):393-399.

42. Marcocci L, Packer L, Droy-Lefaix MT, Sekaki A, Gardès-Albert M: Antioxidant action of Ginkgo biloba extract EGb 761. Methods Enzymol 1994, 234:462-475

43. Chávez-Morales RM, Jaramillo-Juárez F, Posadas del Río FA, ReyesRomero MA, Rodríguez-Vázquez ML, Martínez-Saldaña MC: Protective effect of Ginkgo biloba extract on liver damage by a single dose of $\mathrm{CCl}_{4}$ in male rats. Hum Exp Toxicol 2011, 30(3):209-216.

44. Wang SS, Zheng ZG, Weng YQ, Yu YJ, Zhang DF, Fan WH, Dai RH, Hu ZB: Angiogenesis and anti-angiogenesis activity of Chinese medicinal herbal extracts. Life Sciences 2004, 74:2467-2478.

45. Fong TA, Shawver LK, Sun L, Tang $C$, App H, Powell TJ, Kim YH, Schreck R, Wang X, Risau W, Ullrich A, Hirth KP, McMahon G: SU5416 is a potent and selective inhibitor of the vascular endothelial growth factor receptor (Flk-1/KDR) that inhibits tyrosine kinase catalysis, tumor vascularization, and growth of multiple tumor types. Cancer Res 1999, 59:99-106.

46. Liu JG, Zhao HJ, Liu YJ, Wang XL: Effect of selenium-enriched malt on VEGF and several relevant angiogenic cytokines in diethylnitrosamineinduced hepatocarcinomarats. J Trace Elem Med Biol 2010, 24(1):52-57.

47. Jozkowicz A, Cooke JP, Guevara I, Huk I, Funovics P, Pachinger O, Weidinger F, Dulac J: Genetic augmentation of nitric oxide synthase increases the vascular generation of VEGF. Cardiovascular Research 2001, 51:773-783.
48. Turlin B, Le Quilleuc D, Leroyer P, Brissot P, Deugnier $Y$, Loréal O: High vascular endothelial growth factor (VEGF) expression in chemicallyinduced hepatic microcancers in mice. J Hepatol 2002, 37(5):620-624.

49. Mise M, Arii S, Higashituji H, Furutani M, Niwano M, Harada T, Ishigami S, Toda Y, Nakayama H, Fukumoto M, Fujita J, Imamura M: Clinical significance of vascular endothelial growth factor and basic fibroblastic growth factor gene expression in liver tumor. Hepatology 1996, 23:455-464.

50. Jiang $C$, Agarwal R, Lü J: Anti-Angiogenic Potential of a Cancer Chemopreventive Flavonoid Antioxidant, Silymarin: Inhibition of Key Attributes of Vascular Endothelial Cells and Angiogenic Cytokine Secretion by Cancer Epithelial Cells. Biochem Biophys Res Commun 2000, 276(1):371-378.

51. Hiraoka N, Allen E, Apel IJ, Gyetko MR, Weiss SJ: Matrix metalloproteinases regulate neovascularization by acting as pericellular fibrinolysins. Cell 1998, 95:365-377.

52. Raina K, Rajamanickam S, Singh RP, Deep G, Chittezhath M, Agarwal R: Stage-specific inhibitory effects and associated mechanisms of silibinin on tumor progression and metastasis in transgenic adenocarcinoma of the mouse prostate model. Cancer Res 2008, 68(16):6822-6830.

53. Koltermann A, Liebl J, Fürst R, Ammer H, Vollmar AM, Zahler S: Ginkgo biloba extract EGb 761 exerts anti-angiogenic effects via activation of tyrosine phosphatases. J Cell Mol Med 2009, 13(8B):2122-2130.

54. McCourt M, Wang JH, Sookhai S, Redmond HP: Proinflammatory mediators stimulate neutrophil-directed angiogenesis. Arch Surg 1999, 134:1325-1331.

55. McCourt M, Wang JH, Sookhai S, Redmond HP: Activated human neutrophils release hepatocyte growth factor/scatter factor. Eur J Surg Oncol 2001, 27:396-403.

56. Tice RR, Andrews PW, Hirai O, Singh NP: The single cell gel (SCG) assay: an electrophoretic technique for the detection of DNA damage in individual cells. Adv Exp Med Biol 1991, 283:157-164.

57. Fairbrain DW, Walburger DK, Fairbrain JJ, O'Neill KL: Key morphologic changes and DNA strand breaks in human lymphoid cells: discriminating apoptosis from necrosis. Scanning 1996, 18:407-416.

58. Horst MA, Ong TP, Jordão AA Jr, Vannucchi H, Moreno FS, Lajolo FM: Water extracts of cabbage and kale inhibit ex vivo $\mathrm{H}_{2} \mathrm{O}_{2}$-induced DNA damage but not rat hepatocarcinogenesis. Braz J Med Biol Res 2010, 43(3):242-248.

59. Saravanan R, Pugalendi KV: Assessment of the pharmacological effect of silymarin on ethanol-induced DNA damage by single-cell gel electrophoresis. Indian J Pharmacol 2005, 37:261-262.

60. Yu TW, Anderson D: Reactive oxygen species-induced DNA damage and its modification: A chemical investigation. Mutat Res 1997, 379:201-210.

61. Thiagarajan G, Chandani S, Harinarayana Rao S, Samuni AM, Chandrasekaran K, Balasubramanian D: Molecular and cellular assessment of ginkgo biloba extract as a possible ophthalmic drug. Exp Eye Res 2002, 75(4):421-430.

62. Keles MS, Demirci N, Yildirim A, Atamanalp SS, Altinkaynak K: Protective effects of N-acetylcysteine and Ginkgo biloba extract on ischaemiareperfusion-induced hepatic DNA damage in rats. Clin Exp Med 2008, 8(4):193-198.

63. Min K, Ebeler SE: Quercetin inhibits hydrogen peroxide-induced DNA damage and enhances DNA repair in Caco-2 cells. Food Chem Toxicol 2009, 47(11):2716-2722.

64. Jahan MS, Vani G, Shyamaladevi CS: Anti-carcinogenic Effect of Solarium trilobatum in Diethylnitrosamine Induced and Phenobarbital Promoted Hepatocarcinogenesis in Rats. Asian J Biochem 2011, 6(1):74-81.

65. Sivaramakrishnan V, Shilpa PN, Praveen Kumar VR, Niranjali Devaraj S: Attenuation of $\mathrm{N}$-nitrosodiethylamine induced hepatocellular carcinogenesis by a novel flavonol-Morin. Chem Biol Interact 2008, 171:79-88.

66. Dias MC, Rodrigues MA, Reimberg MC, Barbisan LF: Protective effects of Ginkgo biloba against rat liver carcinogenesis. Chem Biol Interact 2008, 173(1):32-42.

67. Gupta C, Vikram A, Tripathi DN, Ramarao P, Jena GB: Antioxidant and Antimutagenic Effect of Quercetin against DEN Induced Hepatotoxicity in Rat. Phytother Res 2010, 24:119-128.

doi:10.1186/1475-2867-11-38

Cite this article as: El Mesallamy et al:: The chemopreventive effect of Ginkgo biloba and Silybum marianum extracts on hepatocarcinogenesis in rats. Cancer Cell International 2011 11:38. 